\title{
Open innovation practices in the development of wind energy supply chain: an exploratory analysis of the literature
}

\author{
Mario Orestes Aguirre González, Marcela Squires Galvão, Samira Yusef Araújo de Falani, \\ Joeberson dos Santos Gonçalves, Lorena Tâmara Sena da Silva \\ Federal University of Rio Grande do Norte
}

e-mails: mario@ct.ufrn.br; marcela_squires@yahoo.com.br; samyusef14@hotmail.com; joeberson.sp@hotmail.com; lorena.tss@gmail.com

\begin{abstract}
The open innovation approach and its practice in technological innovation projects have been revealed in the literature and observed in practice companies as an old phenomenon. What differentiates its current use is that today its practice occurs in a systematic and formalized form in companies. This paper carried out a bibliographic-exploratory research about the wind power supply chain and it analyzes how technological innovations made their development possible. The study focuses specifically on exploring within the technological innovations occurred in the chain wind power, as the innovative approach followed by developers organizations. Results indicate that open innovation practices were essential for the success of economic and technological feasibility for the development of such chain, primarily by what happened partnership between the manufacturers of major components (aero generators, towers, blades) wind energy, research institutes, laboratories, universities and federal governments through incentive policies.
\end{abstract}

Keywords: technological development, wind energy supply chain, open innovation.

\section{Introduction}

The current economic environment requires a market response in less time and with greater product innovation. In organizations, the Research and Development department has the responsibility for carrying out the research on new production alternatives of products and services at affordable costs, providing competitive advantage to companies. The generation of residues and the emission of pollutants that damage the environment grow in direct proportion to consumption. Thus, the search for sustainable and ecologically correct products is generating new market opportunities, since environmental issues present themselves as strategic targets in the corporate environment.

The partnership among an organization and other companies or research institutes seeking to exchange market information and technology to innovative ideas that arise or solutions to existing ideas, characterize the practice of open innovation. According to Chesbrough (2003, 2011), the open innovation occurs when the company adds external knowledge and, along with internal knowledge, it generates value for the organization. That is, the boundary between the firm and its environment is porous assuming exchange of expertise.

One of the sectors that have shown a significant amount of research in the area of sustainability is the energy sector, whose consumption increases, progressively, both in industry and commerce, and also in residences. This concern consumption along with sustainable development justifies the search for new renewable energy sources, among them wind and solar energy (DUTRA, 2001).

Wind energy presents itself as an excellent alternative in generating clean energy. In Brazil, the increase in the generation of wind energy increased from $145 \mathrm{MW}$ in 2007 to $2.3 \mathrm{GW}$ in 2012 (AGÊNCIA..., 2012). The Northeast region in Brazil stands out as a potential region of climate and weather conditions with winds of high quality, measured by indicators speed and continuity. However, the expansion of wind energy too occurred due to the economic and technological feasibility of the main components of a wind farm as a result of the development of more efficient and economical technologies. According to data of the Agência Nacional de Energia Elétrica - ANEEL (AGÊNCIA..., 2012), the price of electricity sold, from wind farms, fell from R\$305/MWh in 2005 to R\$ 100.9/MWh in 2011.

This paper aims to analyze the application of open innovation approach in technological innovation projects of equipment and components supply chain of wind energy. For this, was conducted a bibliographic-exploratory study on the topics: open innovation, technological innovation and chain of wind energy. Further, the study was complemented with technical reports and research on the development of technologies of wind energy supply chain.

The paper is organized into five topics. The first one describes the introduction and the purpose of the research. Topics 2, 3 and 4 present a brief bibliographic review on 
the basis of the topic under study: open innovation, wind energy and technological innovation in the of wind energy chain, respectively. Finally, the fifth section deals the final considerations of the study.

\section{Open innovation}

The traditional model of innovation - closed innovation (see Figure 1) - requires control in innovations, in other words, companies must generate their own ideas without sharing their clients and partners with the external environment. The benefits and profits from innovation are reinvested in the company to new research. However, the mentality has changed and businesses were opening their research to other companies, organizations and their customers. Therefore, when adding external knowledge with internal knowledge, it increases the value of the organization, so they started to practice the new innovation model - open innovation (see Figure 2) (CHESBROUGH, 2003).

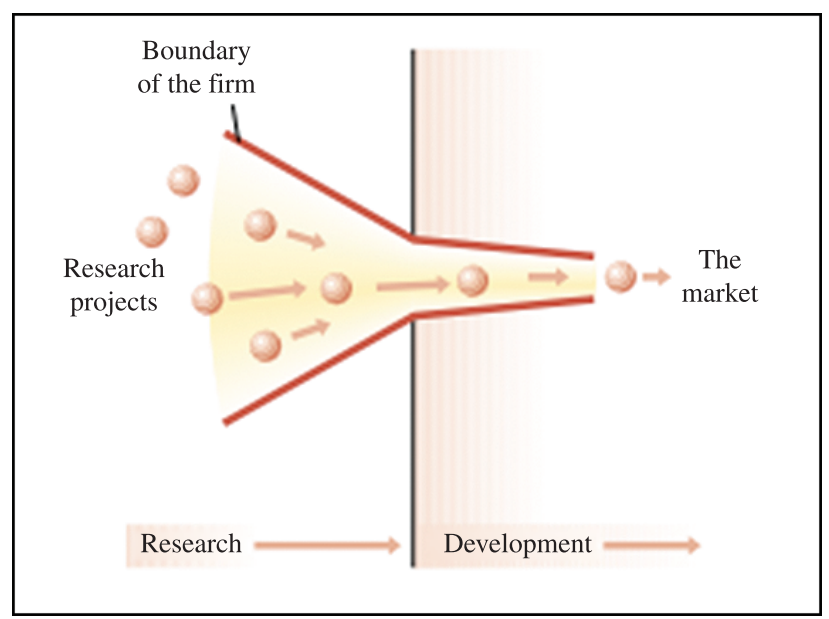

Figure 1. Model of closed innovation. Source: Chesbrough (2003).

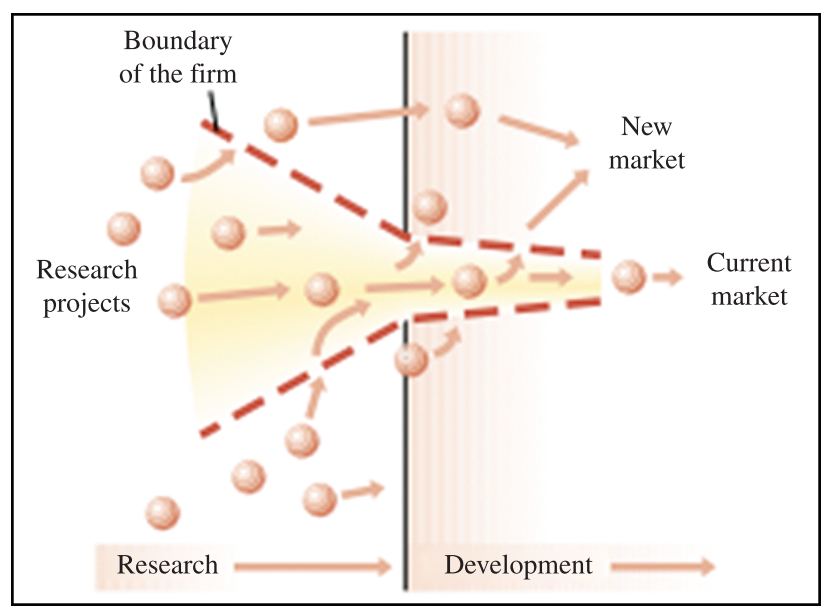

Figure 2. Model of open innovation. Source: Chesbrough (2003).
The difference between these two approaches is in the way enterprises organize their innovation processes. According to Chesbrough (2003), the process of research and development, which is exclusively internal of companies, discriminates the good ideas, which are not presented as good, so that only the best are sold. Though, the open innovation still has the ability to retrieve projects that seem poor, but may become useful during its development.

Organizational leaders must understand the practice of this approach in order to be adopted in accordance with the company's business model, because every change has an impact on the organization, as sharing common vision and mission with partners; changing systems, processes, values, culture of the company as an entire; emergence of opportunities and threats. Leaders need to provide even more motivation, confidence to performance in the team so that everyone is looking for the same common aim.

The open innovation approach shows up differently for small and large businesses. According to Lindegaard (2011a) the main features that link these differences are:

- Speed in decision-making - in small businesses, due to lack of bureaucracy, decisions are made more quickly. Though, the practice of open innovation in small businesses progresses more slowly than in large firms. The latter suffer pressure from the first ome in order to act faster than they are;

- Attitude to risk - when a small business is still starting on the market, the whole business is a risk. But, just as in speed, when talking about open innovation, both types of company may, due to their differences, do not relate well; and

- Resource Allocation - in small businesses, every feature is relevant to the company, while in large organizations, this narrow view of importance of resources is more malleable.

These differences must be understood by both parties of the the partnership formed for the open innovation practice to be satisfactory.

Lindegaard (2011b) presents a research by the Danish Chamber of Commerce which shows that between the years 2007-2010 only 44\% of Danish companies had conducted some innovation activity in their product, service or process. The research also reports the fact that large companies launch new products more often than small firms.

For the success of chain of any organization, it becomes necessary to seek information from two types (PILLER; IHL, 2009): detailed and accurate knowledge about the needs related to the product - client domain - and the techniques of how to solve these needs - the company domain. Additionally, businesses can contribute to skills, both their employees as their customers, to identify and educate its consumers - a view from the outside - and organize themselves internally - view from the inside. 
According to Huizingh (2011), the concept of open innovation can be understood through the distinction among the terms content, context and process. The content covers the different types of openness of the organization, the main activities of inbound and outbound for innovation and the factors of its effectiveness. The context involves characteristics of the internal and external environment of the company. Finally, the process involves the transition to open innovation (before it was a closed innovation, that is, knowledge and practices belonged exclusively to the company) and practices of innovation.

\section{Wind power}

Wind energy is currently seen as one of the most promising renewable energy sources in the world. It has recorded in recent years a truly remarkable evolution. Figure 3 shows the exponential behavior of installed wind capacity, with the highest concentration currently installed capacity in China, USA and Germany (see Figure 4). In 2010, China became the country with the largest installed capacity in the world, reaching in 2011 its holding of 26.2\% of total installed capacity, followed by the United States that participates with $19.7 \%$ of total installed (GLOBAL..., 2011).

\subsection{Wind power in Asia}

China has abundant exploitable wind resources, both onshore and offshore, due to its large land area and long coast. The commercial potential on earth is between 1,000 and 4,000 GW and its potential in offshore waters of 5-50 m depth is $500 \mathrm{GW}$. China installed approximately $18 \mathrm{GW}$ for the second consecutive year and therefore considering the possibility of the market is entering a consolidation phase to resolve some of the problems created by its high economic growth. In 2011, China remains the market leading global cumulative installed wind capacity with a total of $62.36 \mathrm{GW}$ by the end of year 2011. The Chinese turbine manufacturers appear on the list of GWEC (GLOBAL..., 2011) of the top 10 manufacturers in the world, with Sinovel, Goldwind, Mingyang United Power, among others.

The Indian market has surpassed the mark of $2 \mathrm{GW}$ in 2010 and $3 \mathrm{GW}$ in 2011. The continued increase in demand and political priority for renewable energy has transformed India into one of the most dynamic markets in the world. At the same time, the introduction of a new tax code and uncertainty about the future tax benefits that have driven much of the growth in India to date are of concern to investors (GLOBAL..., 2011). Still, the country has the company Suzlon, considered as one of the leading manufacturers of wind turbines in the world.

\subsection{Wind power in Europe}

Europe installed $10.3 \mathrm{GW}$ in 2011, of which $9.6 \mathrm{GW}$ was installed in the EU-27 (GLOBAL..., 2011). These figures are almost identical to the numbers of 2010, the market, which is a symbol of stability in the European market provided by long-term policy framework for renewable energy. In terms of annual installations, Germany was by far the largest market in 2011, with an installation of $2.09 \mathrm{GW}$ of new capacity. The United Kingdom ranked second with $1.3 \mathrm{GW}$, including $752 \mathrm{MW}$ of offshore capacity, followed by Spain (1.05 GW), Italy (950 MW), France (830 MW), Sweden (763 MW) and Romania (520 MW). Turkey and Poland have also had good years with the installation of $470 \mathrm{MW}$ and $436 \mathrm{MW}$, respectively.

\subsection{Wind power in North America}

The market of wind power in the USA grew in more than $30 \%$ in 2011 , totaling $6.8 \mathrm{GW}$ in 31 states for a total installed capacity of almost $47 \mathrm{GW}$, and cumulative market growth of nearly $17 \%$. Canada had a record year in 2011, the installation of $1.26 \mathrm{GW}$, and passing the value of $1 \mathrm{GW}$ for the first time in a single year, aiming to add $1.5 \mathrm{GW}$ capacity in 2012. Canada has a total installed capacity of $5.3 \mathrm{GW}$ now, and it is on track to meet the target industry set of 10 GW by 2015 (GLOBAL..., 2011).

\subsection{Wind power in Brazil}

In this scenario, Brazil stands out as the most promising market for progress in Latin America, due to the fact that it has many areas with high wind potential, increasing demand for electricity, industry and a solid reliable system of electricity distribution. Brazil has estimated a potential

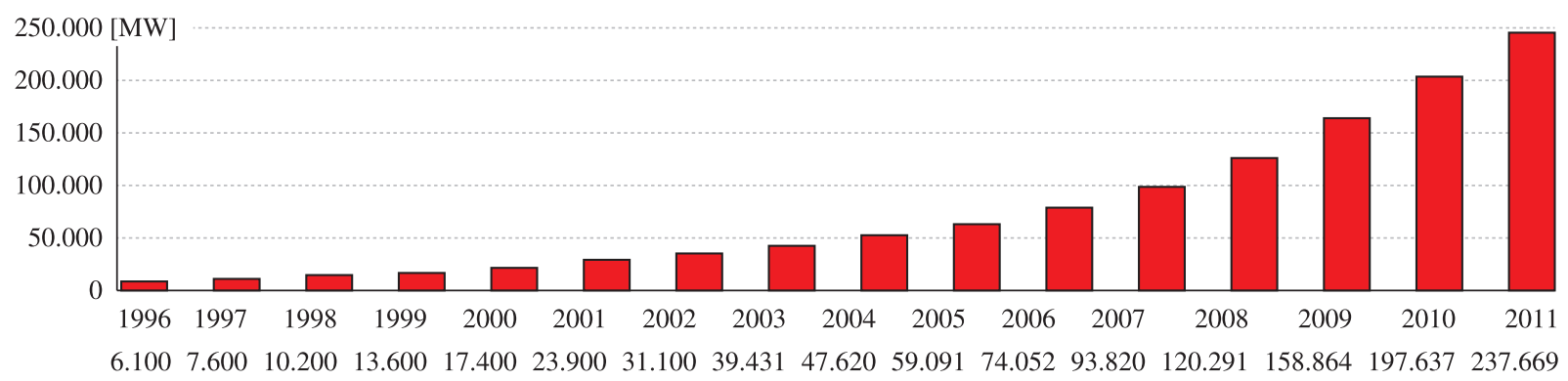

Figure 3. Cumulative global wind capacity installed from 1996 to 2011 (GLOBAL..., 2011). 
capacity of $143 \mathrm{GW}$ of wind power, with most being spread along the northeast coast.

In 2011, the Brazilian wind industry installed $583 \mathrm{MW}$, bringing the total installed capacity to $1.5 \mathrm{GW}$, as shown in Figure 5, representing a 63\% increase in capacity and an increase of $56 \%$ in terms of annual market growth (AGÊNCIA..., 2012; BENNETT, 2010; GLOBAL..., 2010). In October 2012, Brazil reached a value of $2.4 \mathrm{GW}$ and has over $7 \mathrm{GW}$ by 2016 , from the 147 projects currently under construction and another 507 granted.

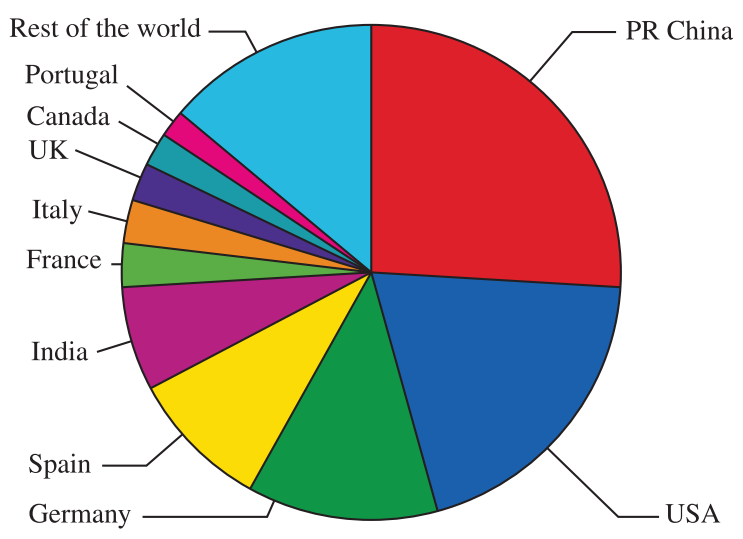

Figure 4. Top 10 in accumulated capacity until December 2011 (GLOBAL..., 2011).

\subsubsection{Wind power in the Northeast of Brazil}

The great wind potential in Brazil is due to wind patterns that are among the best in the world, because in addition to having high speed, they are considered as well-behaved, in other words, without major fluctuations (COSTA; CASOTTI; AZEVEDO, 2009). In the case of wind energy in the Northeast it may be noted that three states correspond largely to the wind generation potential and the winds: Rio Grande do Norte, Ceara and Bahia. Table 1 presents the potential of winds in each region of the country, where the northeast appears in a privileged position, occupying more than $50 \%$ of potential wind generation.

The graph in Figure 6 shows a comparative of the generation of wind energy to the northeast of Brazil, which

Table 1. Potential wind power generation by region.

\begin{tabular}{|c|c|c|}
\hline Region & GW & \% \\
\hline Northeast & 75 & 52,30 \\
\hline Southeast & 29 & 20,71 \\
\hline South & 22,8 & 15,90 \\
\hline North & 12,8 & 8,93 \\
\hline Midwest & 3,1 & 2,16 \\
\hline Total & 143,4 & 100 \\
\hline
\end{tabular}

Source: Adapted from Aneel (AGÊNCIA..., 2012), EPE (EMPRESA..., 2011).

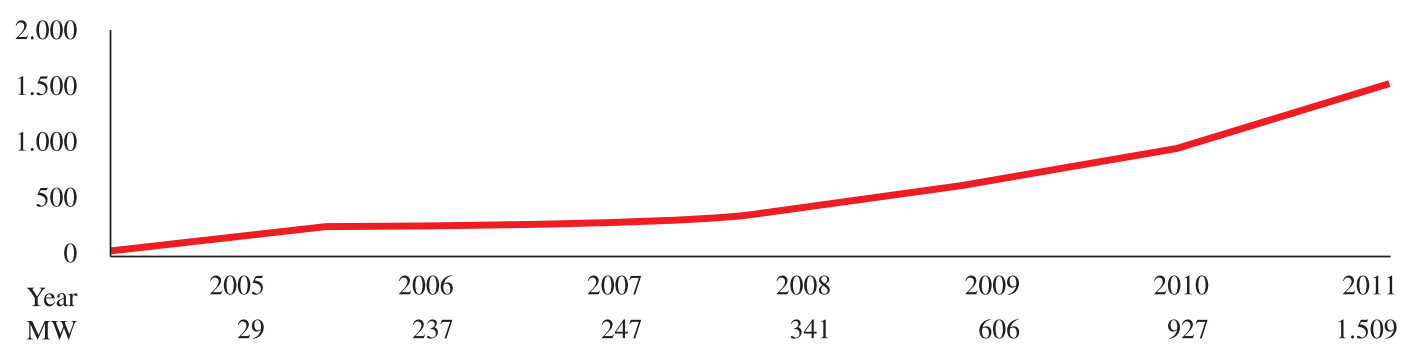

Figure 5. Total installed capacity in Brazil (GLOBAL..., 2011).

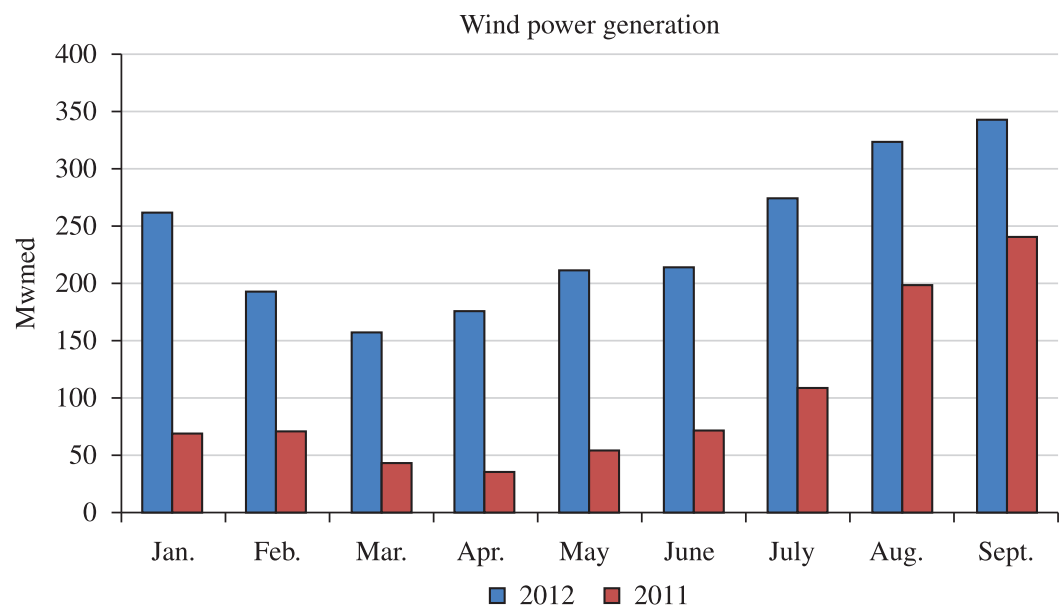

Figure 6. Comparison of wind generation in the years 2011 and 2012 in the Northeast of Brazil. Adapted from Aneel (AGÊNCIA..., 2012). 
comprises a comparison between the years 2011 and 2012 for the months January to September. We can see the preponderance of wind power generation in the current year, 2012, compared to the previous year, with a greater growth of values of generation in the first seven months of the year.

In 2009, the state of Rio Grande do Norte ranked first in terms of enterprises engaged in wind energy auctions. The first auction dedicated exclusively to the marketing wind power resulted in a total of $1.8 \mathrm{GW}$ hired a median sales price of R $\$ 148.39 / \mathrm{MWh}$. With the auction, 71 sold their power plants in 20-year contracts, they are distributed in five states: 18 in Bahia, 21 in Ceara, 23 in Rio Grande do Norte, 8 in Rio Grande do Sul and 1 in Sergipe. In this auction, Rio Grande do Norte had the highest number of approved projects, representing $657 \mathrm{MW}$ of installed capacity.

In 2010, the auctions for alternative sources of electricity resulted in hiring $2.05 \mathrm{GW}$ of installed capacity in projects from wind farms. Overall, 70 wind farms were hired and Rio Grande do Norte was awarded 39 projects, from which 9 are energy reserves, which in total add up to $1.06 \mathrm{GW}$ of power.

In 2011, the Reserve Energy Auction hired 34 wind power projects, totaling 861.1 MW, 405.4 MW of which will be generated in the state of Rio Grande do Norte and spread over 15 wind farms. Four projects in the State of Ceara were included in Reserve Auction A-3. They were, in order of power installed: Catavento Paracuru I (30 MW), São Cristóvão (29.9 MW), São Jorge (27.6 MW) and Santo Antonio de Padua (16.1 MW). Altogether, were applied about \$ 395 million in contracts from 103.6 MW in the State.

Even though Bahia is a beginner in the area of wind power, it runs to increase its importance in the sector. In May 2011, it opened its first wind turbine factory. Installed in the industrial Camaçari, with an initial investment of $\$ 50$ million, the unit belongs to the Spanish company Gamesa.

Currently, Bahia is the second largest state in contracted power in wind energy auctions. When the 52 projects planned to settle in the state are working, they will add about $1.4 \mathrm{GW}$ to the grid. The forecast is that by September 2012, 18 parks are in full operation. The projects total approximately $\$ 6$ billion in investments and are expected to generate between 400 and 600 jobs during operation.

A summary of the wind power projects to the states of Ceara, Rio Grande do Norte and Bahia is shown in Table 2.

\subsection{Cost of wind energy}

The implantation of wind farms is not an alternative well liked by some governments, because their initial investment is still high - structure generation, generation efficiency, availability and serviceability factor (BRONZONATTI; IAROZINSKI NETO, 2008), indicating that even in an embryonic stage. However, the advantages that come with the use of wind power become evident, because according Kaldellis and Zafirakis (2011, p. 1895)

[...] cost of generating electricity in the near future, on land and at sea, maintain values between $50 € / \mathrm{MWh}$ and $80 € / \mathrm{MWh}$, and between $75 € / \mathrm{MWh}$ and $120 € / \mathrm{MWh}$, respectively $[\ldots]$

which makes it competitive when compared with other traditional sources of electricity generation.

This concern with the cost of deployment can be justified by the increase in the price of raw materials such as steel, copper, lead, aluminum and carbon fiber - sub-components of the wind turbines (BLANCO, 2009). However, the expectations around the use of wind energy have changed due to investments in $R \& D$ in various companies around the world. Like China and the USA, with innovations in open innovation approach is being applied to the various components of the wind turbines. This promotes often reduction in the uncertainty of successful results and a reduction in investment costs. Thus, the use of wind energy as a complementary source of power generation increases, since the costs of research and technology with these innovations will decrease (LEICK, 2010; DINICA, 2010). In Brazil, the price of electricity sold from wind farms fell from R\$ 305/MWh in 2005 to R\$ 100.9/MWh in 2011.

Table 2. Associated power projects in the state of Ceara, Rio Grande do Norte and Bahia.

\begin{tabular}{|c|c|c|c|}
\hline State & Source of energy & Situation & Capacity associated (MW) \\
\hline \multirow{4}{*}{ Ceara } & 54 projects of wind power & With its planned construction & $1.309,3$ \\
\cline { 2 - 4 } & 11 projects font Wind & construction & 286,1 \\
\cline { 2 - 4 } & 18 projects of wind power & in operation & 544,4 \\
\hline \multirow{4}{*}{ Rio Grande do Norte } & 60 projects of wind power & With its planned construction & $1.886,2$ \\
\cline { 2 - 4 } & 41 projects of wind power & construction & $1.054,6$ \\
\cline { 2 - 4 } & 13 projects of wind power & in operation & 307,5 \\
\hline \multirow{3}{*}{ Bahia } & 33 Developments in wind power & With its planned construction & 837,3 \\
\cline { 2 - 4 } & 19 Developments in wind power & construction & 432 \\
\cline { 2 - 4 } & 3 Developments in wind power & in operation & 95,2 \\
\hline
\end{tabular}

Source: Adapted from Aneel (AGÊNCIA..., 2012). 


\section{Technological innovation in wind power chain}

According to the Ministry of Science and Technology (BRASIL..., 2011), innovation is the result of cooperative processes involving several agents and capabilities as companies and experts. Innovation can be understood as anything that appears different from the existing one, is a moderate difference - called incremental innovation - or a completely new change, which involves risks in its development - called radical innovation.

The process of technological accumulation and learning technology skills are means of achieving innovation (BELL; PAVITT, 1993). Technological innovation may involve changes in equipment, human resources, or a combination of these methods and may also be introduced in the factors of production or types of production output. Thus, innovation can occur both in the product and in the process the company. A technological product innovation is the "[...] implementation/commercialization of a product with improved performance characteristics [...]" that provide new products to consumers, since the process of technological innovation is the "[...] implantation/adoption of production methods or new approach of marketing [...]" (ORGANIZAÇÃO..., 2004, p. 54).

The advantages that come with technological innovation be it in the process or product of the company, present on the cost advantages through increased productivity and greater market share and gains, and competitive advantage by launching new products in market demands and providing higher margins on production costs. In addition, Hall and Vredenburg (2003) consider that innovations must group the social and environmental needs, as well as consider future generations, in order to align itself to sustainable development.

Upon talking about renewable energy sources, technological innovations represent a reduction in the cost of adoption of a particular technology and its implantation to enlarge the sources of power generation, as has been happening recently with wind energy. The fact is that this advantage is making renewable energy more competitive than some conventional sources, such as fossil fuels.

As examples of innovations, we can cite the ones occurred in Japan, according to Inoue and Miyazaki (2008), regarding to turbines, which speed was increased from $20 \mathrm{rpm}$ to $1800 \mathrm{rpm}$, to the control of angle of the blade to maximize performance the generator, the rotation speed to maximize the efficiency of the wind turbine by changing the rotational speed in about $40 \%$ of rated speed, and in another transmission using the generator, which leads to turbines operating at low speed obtaining greater efficiency.

Another practice of open innovation was the creation of a completely new design for the blades of wind turbines, being shaped humpback whale flippers, designed from the studies of Dr. Frank Fish, a professor of biology at West Chester
University of Pennsylvania, which developed work related to biomimicry, the study of biological structures and their functions, looking to learn from nature and apply to imitate it in science. Later, it was discovered that the irregular structures of whale flippers resulted in 32\% less drag and an $8 \%$ increase in support (WHALEPOWER, 2009).

The Italian company Kitegen created a system of power generation using an open innovation strategy using wind kites flying at 1000 meters of altitude instead of propellers. The movements of the kites are controlled by a computer that calculates the best angle and position to capture the strongest winds. Energy is generated when the wind carries the kite from one place to another rotating structure and transforming that energy into motive power. The company reveals that his invention generates the same energy than 150 wind turbines (INOVAÇÃO..., 2012).

Ohya and Karasudani (2010) from the University of Kyushu in Japan developed a new system of wind turbine from studies of fluid dynamics consisting of a casing diffuser with a wide brim ring at the periphery of output and a wind turbine on its interior. The wind turbine, that is wrapped with a diffuser brimmed, generates increased potency by a factor of approximately 2.5 compared with a wind turbine bare for a given diameter of the turbine and the wind speed.

The company Wave Motor Group along with researchers Leung, Deng and Leung (2011) of the City University of Hong Kong have developed a micro wind turbine designed to capture wind energy in urban and rural environments. The turbine system MicroWind is flexible in size and connected to small generators that generate electricity on-site for easy application. Owing to the plastic composition of the blades, the system has low cost and can be driven by a wind speed as low as $2 \mathrm{~m} / \mathrm{s}$. In order to extract more wind energy, several of these micro-wind turbines can be connected by their external gears in an array to increase their contact area and hence more potency.

The examples cited in the development of the technology generated in this last decade, their practice was partnerships settled among different agents: research groups, research promotion agencies, manufacturers, suppliers of technological parts and communities where there is potential for generating wind energy. Considering the definition of open innovation approach we consider that it was important for the development of technical and economic feasibility of wind power supply chain.

\section{Conclusions}

In times of growing consumption, the quest for differentiation in the market requires companies that maintain constant updates at least on par with the market. Developing technology and/or new products in smaller time at a feasible cost makes company publish their ideas and problems to the market in order to find innovative solutions 
faster. Thus, the practice of open innovation reduces this period within technological development or offering new products while providing competitive advantage to the company in relation to the expansion of its market knowledge and technological solution.

In general, in the wind power supply chain, the open innovation approach has reached many goals such as reducing costs of equipment and components of the wind farms and more efficiency in the transformation of kinetic energy of wind into electrical energy. However, glimpses of a better use of open innovation approaches not only the innovative components of a wind farm, but also the production process and organizational innovation along the chain, with the guideline forming a supply chain highly integrated partnerships and relationships between companies, better visibility of the process, development of new custom components reality of markets, greater prediction for meeting production schedules and capacity and continuous improvement in the value chain.

The concentration of the practice of open innovation in the Asian continent, highlighting Japan and Hong Kong is highlighted, despite having little installed capacity of wind power, it is estimated that this concentration is due to large amount of investment and financing technological innovation in the region. In Europe, a research with open innovation approach occurred in Italy, despite the low significance of the installed capacity in the country. While countries like Denmark and Germany have activities focused to this sector, it has not been verified any technological developments in recent years with operational innovation approach. In North America, a practice of open innovation was found in Pennsylvania - USA, which aligns with this big growth registered in the USA wind market last year.

In Brazil, two reasons can be given for the expansion of wind energy. First, the international technological development, for the last two decades, especially countries like Denmark, Germany, Japan, China, India and Italy, in which occurred mainly through the participation of technology partners, among them: manufacturers of key components (turbines, towers and blades), research groups, laboratories, universities and research funding agencies. This technological development occurred in the world, enabled the transfer of technology to Brazil, carried by the abrupt increase in installation manufacturers of wind turbines from one companies of 2005 to ten companies by 2012 .

Second, due to incentives from the Brazilian government by the inclusion in the auction for the purchase of energy coming from the wind power. This practice reduced uncertainty of the investors in this sector and aligned with the wind potential of the country, by their extent of land and the quality of the wind, allowed him to have an abrupt growth, from the year 2002 with a generation of $115 \mathrm{MW}$ for a generation of more than $2 \mathrm{GW}$ in 2012 .
Nowadays, the practice of open innovation has been happening for the development of Brazilian technology, because it is questioned that the equipment used in recent wind farms have been designed taking into account climatic conditions very different to the Brazilian northeast region. In response to this, and the initiative of a manufacturer of wind turbines, FINEP is funding the first national wind turbine, and have with participants: Research Laboratories, Universities, Government, Research Centers and Manufacturer of wind turbines.

Therefore, research in this area should be developed so that more wind farms are located, because its energy source is renewable, does not affect the environment, with a strong contribution to the energy mix of the country. In particular for the Brazilian northeast region, it represents an opportunity for sustainable development, since the areas of greatest wind potential are located in municipalities with low HDI - Human Development Index. For this finding, it is recommended to conduct prospective studies of open innovation approach involving local governments, the population of the municipalities and authorities regulating the environment in order to take practice what is known as the technological innovation chain that provides development for all its stakeholders.

\section{References}

AGÊNCIA NACIONAL DEENERGIA ELÉTRICA-ANEEL. Disponível em: <www.aneel.gov.br>. Acesso em: 12 out. 2012.

BELL, M.; PAVITT, K. Technological accumulation and industrial growth: contrast between developed and developing countries. Industrial and Corporate Change, v. 2 , n. 2 , p. $157-210$, 1993. http://dx.doi.org/10.1093/ icc/2.1.157

BENNETT, C. Latin American Wind Takes Shapes. Renewable Energy Focus, 2010.

BLANCO, M. I. The Economics of Wind Energy. Renewable and Sustainable Energy Reviews, v. 13, n. 6-7, p. 1372-1382, 2009. http://dx.doi.org/10.1016/j. rser.2008.09.004

BRASIL. Ministério de Ciência e Tecnologia. Portal Inovação. Disponível em: <http://www.portalinovacao.mct. gov.br/pi/>. Acesso em: 31 maio 2011.

BRONZONATTI, F. L.; IAROZINSKI NETO, A. Matrizes Energéticas no Brasil: Cenário 2010-2030. In: ENCONTRO NACIONAL DE ENGENHARIA DE PRODUÇÃO, 28., 2008, Rio de Janeiro. Anais eletrônicos... Rio de Janeiro: ABEPRO, 2008.

CHESBROUGH, H. W. Open Services Innovation: Rethinking Your Business to Grow and Compete in a New Era [Hardcover]. San Francisco: Wiley, 2011. 
CHESBROUGH, H. W. The era of Open Innovation. MIT Sloan Management Review, v. 44, n. 3, p. 34-41, 2003. http://dx.doi.org/10.1007/978-88-470-1980-5

COSTA, R. L.; CASOTTI, B. P.; AZEVEDO, R. L. S. Um Panorama da Indústria de Bens de Capital Relacionados à Energia Eólica. BNDES Setorial, n. 29, p. 229-278, mar. 2009.

DINICA, V. Wind Technology: A Framework for the Evolution of Innovations' Impacts on the Diffusion Potential. Sustainability, v. 2, n. 3, p. 757-782, 2010. http://dx.doi. org/10.3390/su2030757

DUTRA, R. M. Viabilidade técnico-econômica da energia eólica face ao novo marco regulatório do setor Elétrico brasileiro. 2001. Dissertação (Mestrado em Ciências em Planejamento Energético)-Universidade Federal do Rio de Janeiro, Rio de Janeiro, 2001.

EMPRESA DE PESQUISA ENERGÉTICA - EPE. Contratação no Leilão de Reserva totaliza 1.218,1 MW, através de 41 usinas. São Paulo, 2011. Informe à Imprensa: Leilão de Energia de Reserva 2011.

GLOBAL WIND ENERGY COUNCIL - GWEC. Global Wind Report-Annual market update 2010. GWEC, 2010.

GLOBAL WIND ENERGY COUNCIL - GWEC. Global Wind Report-Annual market update 2011. GWEC, 2011.

HALL, J.; VREDENBURG, H. The challenges of innovating for sustainable development. Mit Sloan Management Review, p. 61-68, 2003.

HUIZINGH, E. K. R. E. Open Innovation: State of the art and future perspectives. Technovation, v. 31, n. 1, p. 2-9, 2011. http://dx.doi.org/10.1016/j.technovation.2010.10.002

INOUE, Y.; MIYAZAKI, K. Technological innovation and diffusion of wind power in Japan. Technological Forecasting and Social Change, v. 75, n. 8, p. 1303-1323, 2008. http:// dx.doi.org/10.1016/j.techfore.2008.01.001

INOVAÇÃO TECNOLÓGICA. Turbina eólica voadora vai buscar ventos nas alturas. Campinas: Inovação Tecnológica, 2012. Redação do Site Inovação Tecnológica - 05/03/2012. Disponível em: <http://www. inovacaotecnologica.com.br/index.php $>$. Acesso em: 10 set. 2012.
KALDELLIS, J. K.; ZAFIRAKIS, D. The Wind energy (r) evolution: A short review of a long history. Renewable Energy, v. 36, n. 7, p. 1887-1901, 2011. http://dx.doi. org/10.1016/j.renene.2011.01.002

LEICK, D. Innovations in wind power technology. Renewable Energy Focus, v. 11, n. 2, p. 24-28,30,32-35, 2010.

LEUNG, D. Y. C.; DENG, Y.; LEUNG, M. K. H. Parametric study of a fan-bladed micro-wind turbine. Proceedings of the Institution of Mechanical Engineers, Part A: Journal of Power and Energy, v. 225, n. 8, p. 1120-1131, 2011. http:// dx.doi.org/10.1177/0957650911413974

LINDEGAARD, S. Big vs. Small companies: Where are the differences on innovation? 15inno by Stefan Lindegaard, 2011a. Disponível em: <http://www.15inno. com/2011/04/28/bigvssmalldifferences/>. Acesso em: 07 maio 2011 .

LINDEGAARD, S. Only 44\% of companies innovate! 15 inno by Stefan Lindegaard, 2011b. Disponível em: <http:// www. 15 inno.com/2011/05/17/44percent/>. Acesso em: 07 maio. 2011.

OHYA, Y.; KARASUDANI, T. A shrouded wind turbine generating high output power with wind-lens technology. Energies, v. 3, n. 4, p. 634-649, 2010. http://dx.doi. org/10.3390/en3040634

ORGA NIZAÇÃO PARA COOPERAÇÃO E DESENVOLVIMENTO ECONÔMICO - OCDE. Financiadora de Estudos e Projetos - FINEP. Proposta de Diretrizes para Coleta e Interpretação de Dados sobre Inovação Tecnológica. FINEP, 2004. Manual de OSLO.

PILLER, F.; IHL, C. Open innovation with customers: Foundations, competences and international trends. Technology and Innovation Management Group. RWTH Aachen University, 2009. Disponível em: <http:// www.internationalmonitoring.com/fileadmin/Downloads/ Trendstudien/Piller-Ihl_Open_Innovation_with_Customers. pdf>. Acesso em 07 maio. 2011.

WHALEPOWER. Finalist For Major International Award. 2009. Disponível em: http://www.whalepower.com/ drupal/?q=node/6. Acessado em 10 de novembro de 2011. 